Resumen por el autor, John H. Gerould.

Las orugas azules-verdes; el orígen y ecología de una mutación en el color de la hemolinfa de Colias (Eurymus) philodice.

En Agosto de 1920 aparecieron cuarenta y cuatro orugas azules-verdes de ambos sexos en la progenie de una hembra salvaje blanca de C. philodice (bisabuela) cruzada entre sí durante dos generaciones. Las orugas que formaban las generaciones de los abuelos buy padres eran normales, presentando la coloración protectiva verde amarillenta. Las mutaciones recesivas azules fueron el resultado de tres cruzamientos de padres verdes heterozigóticos, cuyos descendientes aparecieron en la proporción 3:1. A partir dè este momento azul azul produjo la misma clase de descendientes; las formas heterozigóticas verde azul produjeron individuos verdes y azules. Puesto que uno de los progenitores de cada uno de los pares de abuelos era verde heterozigótico, el otro verde homozigótico, es probable que lo mismo sucediese en la pareja salvaje originaria; su cruzamiento entre sí permitió manifestarse al factor latente recesivo. La hemolinfa de la mutación, lo mismo que su piel, es azul-verde. Puesto que el color de la hemolinfa del individuo normal amarilloverde se debe a un pigmento amarillo (xantofiloide) más un pigmento azul-verde, derivados ambos de la clorofila de la planta que sirvió de alimento, el gene de la mutación (que actúa probablemente desde el núcleo de las células del epitelio intestinal durante la digestion) evidentemente ataca y destruye al primero, dejando al segundo como colorante de la hemolinfa. En la cutícula blanca de la ninfa de color azul-verde, en el ojo de la mariposa y en el huevo recién puesto falta como consecuencia un componente amarillo normal. El color de las alas esindependiente de la mutación. Los Bracónidos parásitos que emerjen de las larvas normales amarillas-verdes tejen capullos de color amarillo vivo; los de las larvas azul-verdes, producen capullos blancos. Los gorriones eliminaron las orugas azules de un cultivo a la intemperie que se dejó descubierto durante doce dias, dejando sin molestarlas a la mayor parte de las que presentaban la coloración protectiva verde. 
AUTHOR'S ABSTRACT OF THIS PAPER ISEUED BY THE GIBLIOGRAPHIC SERVICE, OCTOBER 17

\title{
BLUE-GREEN CATERPILLARS: THE ORIGIN AND ECOLOGY OF A MUTUATION IN HEMOLYMPH COLOR IN COLIAS (EURYMUS) PHILODICE
}

\author{
JOHN H. GEROULD \\ Dartmouth College, Hanover, New Hampshire
}

ONE TEXT FIGURE AND ONE COLORED PLATE (SIX FIGURES)

CONTENTS

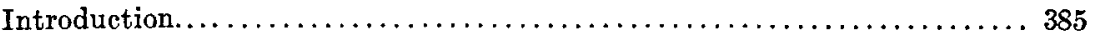

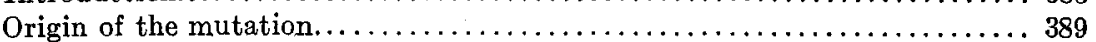

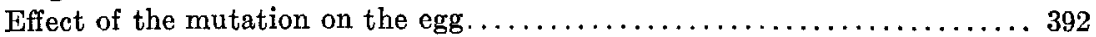

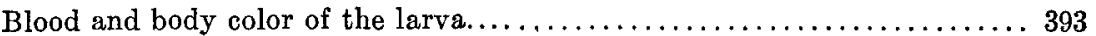

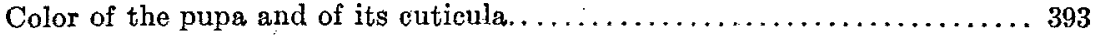

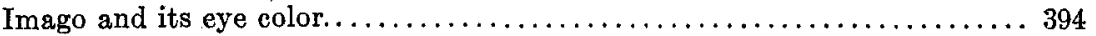

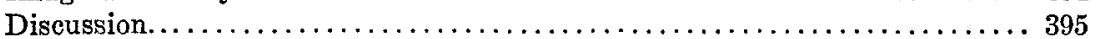

Effect of blue-green blood on the cocoon-color of a parasite........... 396

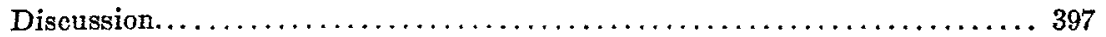

How lamarckian factors may reach the genes. . . . . . . . . . . . . . . . 398

Action of environmental factors and genes upon certain blood pigments... . 400

Inadequacy of the presence-absence hypothesis to explain grass-green vs.

blue-green blood color.............................. 402

Elimination of blue-green mutants by natural selection. . . . . . . . . 402

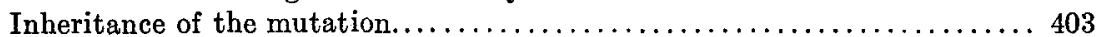

Table 1............................................. 404

Vigor of the mutant caterpillars......................... 405

Similar mutants in plants and animals...................... 406

Factors affecting the color of blood and cocoon in the silkworm .........4408

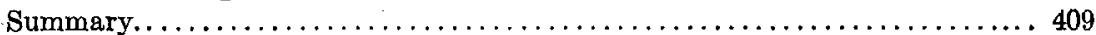

Literature cited................................... 411

\section{INTRODUCTION}

In the course of an investigation into the inheritance of dimorphism (white and yellow female varieties of the butterfly) in Colias philodice involving close inbreeding, a remarkable mutation in blood color occurred during the summer of 1920 . The mutation is extraordinary in that it affects pigments that are derived without much modification from the chlorophyl of 
the food plant and produces a definite change at every stage in the life-history, including the color of the newly laid egg, of the blood and body wall of the caterpillar and pupa, and of the blood and eyes of the adult.

The caterpillar of C. philodice feeds upon clover, and is of a yellow-green hue corresponding so elosely to that of the plant as to be remarkably inconspicuous. Larvae that are feeding in full view of the observer are almost invisible unless in motion or seen in profile. Although the butterfly is common and I have raised thousands of the caterpillars, I have not found in the open field in the twelve seasons that I have worked upon this species as many, probably, as twelve caterpillars. Imagine, then, my surprise when in August, 1920, caterpillars that were conspicuously blue made their appearance in two of my cultures upon potted clover plants in the greenhouse and my further astonishment when a similar state of affairs was soon afterwards discovered in an outdoor culture upon a series of clover plants covered with cages.

Self-colored blue, or more accurately blue-green, caterpillars are almost unknown in Lepidoptera. Only two species among diurnal butterflies have as yet come to my notice, both European pierids, Anthocharis cardamines and Pieris ergane. None of the species closely related to either, so far as I know, are bluegreen, so that it is possible that each has experienced in its ancestral lineage a mutation like the one here described for Colias philodice, also a pierid. Toyama ('12) mentions the occurrence of blue silkworms, "a Mendelian characteristic and recessive to the normal-skinned characteristic," due, as he states, to the absence of pigment in the hypodermis.

The color sensation that the mutant caterpillars give one against the food plant as a background is like that produced by blueberries on a bush, and it was only by comparing them side by side with blueberries (Vaccinium) that I first convinced myself that they are slightly more green than blue. 'Light porcelain green' of Ridgeway's ('12) Color Standards (pl. 33, $B-G$ ), classed as 'blue-green,' corresponds closely to the ground color of the full-grown caterpillar. 
The evidence regarding the origin of this recessive mutation points to the conclusion that it can be traced back to an individual heterozygous for it, and that it was brought to light by two successive acts of inbreeding, of which the first was a homozygous dominant $x$ heterozygous dominant, and concealed the mutation. By good fortune, however, three out of a total of six matings of the next generation (bred for an entirely different purpose, for blue caterpillars were then unknown) turned out to be combinations of heterozygote $\times$ heterozygote and revealed the bluegreen recessives.

It is a remarkable fact that the mutation affects all the four stages in the life-history. The egg cytoplasm at the time of laying is pure alabaster-white instead of cream-white; the larvae are blue-green, the blue color persisting, though less strikingly, through the pupal stage; the pupal cuticula is white instead of pale brownish-yellow, and the eye color of the adult is bluish 'mineral green' rather than the more strongly yellow 'apple green' of the normal eye. This is the first case, so far as I know, in which eye color in insects is known to be intimately connected with blood color, and in this case probably directly determined by the physicochemical nature of the hemolymph.

That the blood-color of the pupa determines the color of its cast cuticula, turning it white, is corroborated by the fact that the silk spun by certain parasitic Hymenoptera (Braconid larvae) emerging from a blue-green caterpillar is white, instead of goldenyellow, the normal cocoon-color of the same species of parasite feeding upon normal yellow-green caterpillars.

This mutation strengthens the evidence that green caterpillar color is not unmodified dissolved chlorophyl, but that the latter in being absorbed through the wall of the intestine into the hemolymph undergoes certain not very profound changes, as it combines with the proteids suspended in the plasma. In the present case the yellow component of chlorophyl, xanthophyl, is evidently broken down or decolorized by a recessive gene, or hereditary chromosomal enzyme, acting locally from the nuclei of the cells of the intestinal epithelium upon the digested leafgreen during its absorption into the hemolymph. The recessive 
gene probably destroys xanthophyl, but leaves intact a pigment derived from the blue-green component of chlorophyl proper, called chlorophyl $a$. The nature of the physicochemical change involved, however, will be the subject of further investigation.

All the recent investigations into the chemistry of green pigments in the hemolymph of plant-eating caterpillars that have come to the writer's attention (e.g., Dubois, '09; Steche, '12; Geyer, '13, and Przibram, '13) support the conclusion of Poulton ('85, '93) that these green and yellow pigments are absorbed into the blood without undergoing fundamental changes. The different pigments, however, xanthophyl and chlorophyllin (chlorophyls $a$ and $b$ ) are not absorbed in equal degree in the two sexes, according to Steche ('12) and Geyer ('13) for, while the blood of the female receives both chlorophyllin and xanthophyl in proportions similar to those that occur in the normal leaf and is consequently in certain species greenish, that of the male of the same species contains only modified xanthophyl, or else none of these pigments whatever, and is accordingly yellowish or colorless. Thus, presumably, in the male the cells of the walls of the intestine produce a metabolic reaction upon these pigments, destroying chlorophyllin and in some cases xanthophyl also, while the corresponding cells in the female have no such effect. That this breaking up of the green pigment in the male is not due to an enzyme in the hemolymph itself, and accordingly should be ascribed to the action of the intestinal epithelium, is shown by the fact that mixing the blood of the male with that of the female does not decolorize the latter.

The blue-green mutant caterpillars of C. philodice, however, are equally distributed between the two sexes, and the same is true of grass-green larvae heterozygous for blue-green. In this case xanthophyl is destroyed, not chlorophyllin, and the decolorizing gene is not sex-limited. Whether a sex-difference exists between the blood pigment of the male and female in C. philodice is still unknown to me. In the common cabbage butterfly,

I A series of observations on $P$. rapae that I have recently made show wellmarked individual variations such as Guyer has described, but those that $\mathrm{I}$ observed were not sex-limited. 
Pieris rapae, however, a somewhat closely allied form, Geyer found the hemolymph of the male caterpillar to be light yellow, that of the female, bright green.

The blue-green caterpillars had been under observation only about three months when this paper was written, but the facts regarding the origin of the mutation, the ecological data already obtained, the many-sided relations of the blood pigments and the action upon them of the mutant gene, are so striking and interesting that it seems best to put the case on record as it stood at the close of the first season. I hope later to present a more complete account of the matter, following out some of the many lines of research that are hardly more than pointed out in the present paper.

I wish to acknowledge my deep indebtedness to Prof. A. Ames, to whose skill the exceedingly accurate record of colors upon the plate is in large measure due; to Prof. Leland Griggs and Mr. Kenneth Robes for the photographs themselves; to Mr. A. B. Gahan, of the National Museum, who identified the hymenopterous parasites that attacked the blue caterpillars; to Mr. Rolf C. Syvertsen, who assisted me in rearing the caterpillars and protecting them against disease, and to Mr. C. J. Lyon for assisting me in acquainting myself somewhat with the chemistry of chlorophyl.

I extend my most appreciative thanks to the authorities of The Wistar Institute for providing a plate in colors. Funds necessary for the prosecution of this research were generously furnished first by the President and Treasurer of Dartmouth College, and later by the Carnegie Institution of Washington through the kindness of Dr. A. G. Mayor, to all of whom I make grateful acknowledgment.

\section{ORIGIN OF THE MUTATION}

The fact that the blue-green caterpillars first appeared in rather large numbers ( 25 in one family, $\theta, 18$ in another, $\beta$, text fig. 1 ) in the same generation of inbred stock, and comprised in each case approximately 25 per cent of their respective families or 
broods, shows at once that their parents all were heterozygous for the new character. Moreover, since these heterozygous grass-green-blooded parents were brothers and sisters (family 1920, l) with the exception of one male $\left(s^{157}\right)$ which was a cousin, we must look to the previous generation of adult butterflies $(1920, \phi)$ for the individuals in whose germ cells the mutation may have occurred.

The grass-green caterpillars that became this previous generation were the hibernating offspring of a white-winged female of the preceding autumn. Of the seven individuals of this family that were used in breeding, at least two $\left(\phi^{5} \%\right.$, white-winged, and either $\phi^{8} \rho$, yellow-winged, or her mate $\left.\phi^{3} o^{7}\right)$ were heterozygotes for blood color, but, mating in each case with normal homozygous dominants for blood color, no recessives appeared in their immediate offspring $(1920, \iota, s)$. It seems probable, furthermore, that other heterozygotes for the blue mutation may have existed in this brood, $\phi$, making up probably 50 per cent, but the offspring of only one pair $\left(\phi^{5} \phi \times \phi^{2}=\imath\right)$ were thoroughly tested (giving broods $\beta, \alpha, \theta, v)$. Two other matings ( $\phi^{6} \% \times \phi^{2} \sigma^{7}=\lambda$, and $\phi^{7} \% \times \phi^{1} o^{7}=0$ ) were made, one of which, $\lambda$, was carried no further, while two couples from the other produced only grass-green caterpillars.

Since more than one and possibly 50 per cent of brood $\phi$ were heterozygous for blue, it is probable that the mutation should be traced back to the wild female of the autumn of 1919 or to her mate, as the original heterozygous mutant, else we must suppose that the similar mutation occurring by hypothesis in two of her offspring originated quite independently of each other and of the parental genotype, which would be quite contrary to general principles in heredity. The case illustrates well how a recessive mutation may be transmitted by heterozygotes, outcrossing with normal dominants for many generations, without coming to light. There is reason to suppose that this is often the case under natural conditions and that close inbreeding of the wild stock for a few generations is all that would be necessary to demonstrate the existence of these latent recessive factors. 


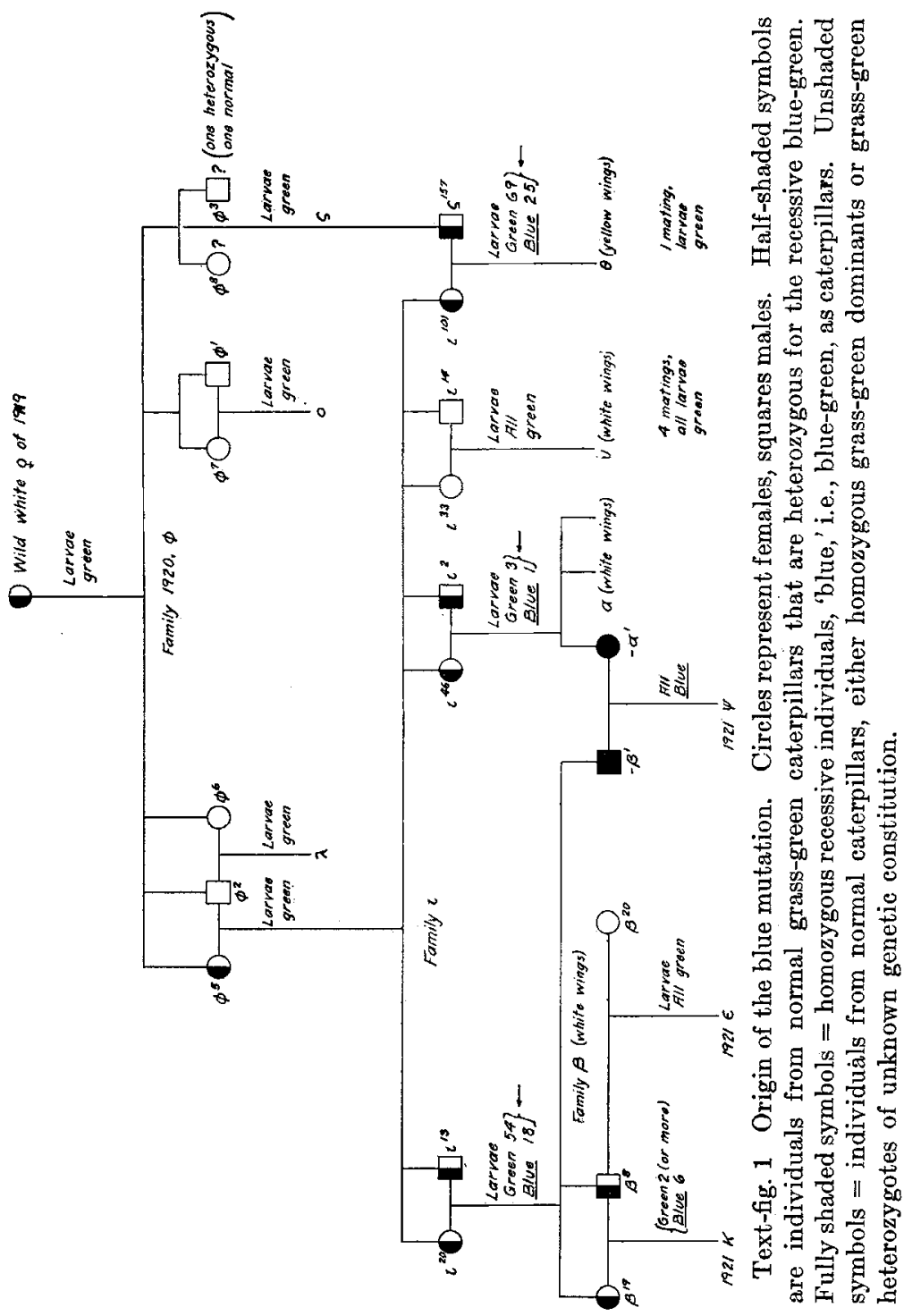


The first sign of the mutation in the life-cycle appears in the cytoplasm of the newly laid egg of a female homozygous for blue-green, which is pure white, like alabaster, rather than the normal cream-white. Thus from the start the protoplasm of the embryo lacks a yellow element. This abnormality in egg color was not observed in the heterozygous stock, but it was found to be true of all the eggs laid by a female that had been a blue caterpillar and on eclosion had been mated to a male that also had been a blue-green larva; that is, these were the fertilized eggs from a pair of recessives with blue-green hemolymph.

The eggs laid by a female heterozygous for blue-green are cream-white, the color of the newly laid egg being determined directly by the blood color of the mother, which appears to be the general rule in Lepidoptera. ${ }^{2}$

As the reader will presently be shown, and at this point must bear in mind, the basis of normal yellow-green blood color is obtained directly from the food. The inherited differential factor in the mutant is a catalyst that destroys xanthophyl rendering the blood blue-green instead of yellow-green and thus indirectly changing the eggs from cream-white to pure white.

During the first twenty-four hours after being laid, the egg, now pale (cream-white or pure white), is going through its early cleavage stages. Presently (probably upon the formation of the blastoderm) it turns red, whereupon, so far as my observations extend, a sharp distinction between the egg of grass-green and blue-green embryo caterpillars is not visible. If then, one of the two maturation divisions is differential, any egg of a female heterozygous for blue-green has an even (50:50) chance of being, at the moment of fertilization and laying, a potential blue-green caterpillar, its nuclei having received the recessive gene that inhibits the further development of yellow. It seems improbable that in the brief period following egg-laying before the now fertilized egg turns red (cleavage stages) the relatively few nuclei of a homozygous embryo from a heterozygous mother

\footnotetext{
${ }^{2}$ Repeated observations made during the following season (1921) confirm these statements.
} 
could decolorize the relatively large mass of yolk-filled protoplasm presumably at the time cream-colored, and make it appear like the egg of a homozygous female pure white.

Moreover, Toyama ('13) has shown that in the silkworm not only the color of the newly laid egg, but even the color of the serosa (containing nuclei that combine both paternal and maternal genes) show only maternal inheritance. The action of the paternal gene is entirely neutralized or masked in reciprocal crosses by some maternal effect, which, in the opinion of the present writer, must lie in the composition and action of the maternal blood.

\section{BLOOD AND BODY COLOR OF THE LARVA}

The mutation is not evident during the first stage of larval development, when the skin is relatively opaque, nor until the end of the second. At that time, just before the second molt when the skin is tightly stretched, the young larva becomes distinctly bluish, and after the second molt conspicuously and even brilliantly blue-green.

Full-grown caterpillars (pl. 1, fig. 1) correspond in color to 'light porcelain green' (Ridgeway, '12, pl. 33, $B-G$ ) above and 'Niagara green' below, running into 'Montpelier green' on the head, which is slightly darker. I am indebted to Prof. A. Ames, an artist and authority in opties, for assistance in this determination. Another mature caterpillar was a shade darker, 'Montpelier green.'

A distinctive feature of the blue-green caterpillar is the entire absence of the pink line that in a normal larva is traced more or less plainly along the middle of the lateral white band running through the stigmata. The pink lateral line of the normal larva is, therefore, a dominant character completely correlated with grass-green hemolymph.

\section{COLOR OF THE PUPA AND OF ITS CUTICULA}

The pupa (fig. 2) is somewhat less blue than the larva, but its hypodermal color is a well-marked discontinuous variation from the normal grass-green hue (fig. 2a). Its ground color corresponds to a blue-green called 'Rejane green' by Ridgeway ('12, pl. $33, G B-G$.) 
The cuticula of the pupa, shed. by the eclosion of the adult (fig. 3, cf. fig. 3a) is white instead of yellow. The blue-green hypodermis of the pupa, deprived of the normal yellow pigment, secretes a white rather than a yellow cuticula.

Observations made in 1921 confirm this, though the posterior abdominal segments of the cast cuticula in some individuals is tinged with brown, probably from excrementous pigments voided by the butterfly before eclosion, and the anterior half of the pupal shell including the wing cases is regularly faintly yellowish and by transmitted light slightly greenish, as shown by figure 3 .

\section{IMAGO AND ITS EYE COLOR}

Color changes in the wings of a butterfly from such striking mutants were to be expected, for it is well known from the work of Mayer (97) and others that the blood that flows into the hollow seales shortly before eclosion provides the pigments of the wing colors, yet no noticeable change in the hue of the scales was produced by the mutation. Thus the two broods containing 25 per cent of blue-green caterpillars, viz., 1920, $\alpha$ and $\beta$ (text fig. 1), were homozygous for white wing colors, while a third, $\theta$, was homozygous for yellow. $\alpha$ and $\beta$ came from white mothers and brother-sister matings within the large family ` [that included 95 white, 28 yellow females, or $3: 1$ ]. The relation between caterpillars and adults within family $\beta$ was as follows: the 29 grass-green caterpillars that reached maturity became ' $\beta$ ' adults $=18$ white $q \%, 11 \sigma^{x} \sigma^{7}$; the 12 surviving blue-green caterpillars became ' $-\beta$ ' adults $=6$ white $\odot ?, 6 \sigma^{x} \sigma^{x}$. $\theta$, on the other hand, came from a yellow mother of this same family, $\iota^{101} \%$, mated with a male of pure yellow stock, $s^{157} \sigma^{7}$, and the 33 mature offspring were all yellow (10 $q$ \% $170^{7} o^{7}$ from grass-green larvae, viz., $\theta$, and 3 \% 우, $3 o^{7} o^{7}$ from blue-green larvae, viz., $\theta$ ).

The blood of the imago, as seen by bleeding an emerging butterfly, continues to be blue-green. It still lacks the yellow element that would have been introduced into it from the food had it not been, in all probability, neutralized or decolorized by an inhibitor. It is evident that this inhibitor of yellow 
pigment has no effect whatever upon the yellow or the white wing pigments that appear in the imago. The latter, while just as literally in the blood as are the former, are chemically quite unlike them. Xanthophyl, from which the yellow element in the normal caterpillar's blood is derived, is said to have the formula $\mathrm{C}_{40} \mathrm{H}_{56} \mathrm{O}_{2}$, while the yellow pigment of Colias, as Hopkins ('94) has shown, is allied to uric acid, $\mathrm{C}_{5} \mathrm{H}_{4} \mathrm{~N}_{4} \mathrm{O}_{3}$.

The eye color of an adult from a blue-green caterpillar (fig. 4, cf. fig. 4a) is strikingly affected by the mutation. In every case there is a noticeable lack of yellow. The eyes of the mutant are 'mineral green' (Ridgeway, '12, pl. 18, 31' $Y-G$ ), rather than 'apple green' (pl. 17, 29' GG-Y). In some mutant individuals this color difference is very marked, while in others it can be detected only by comparing them closely with an individual from a grass-green caterpillar. This change in eye color is probably an effect produced directly by the altered blood deprived of xanthophyl.

This case supplements the principle brought out by Morgan et al. ('15, p. 32) that a single mutation may affect many parts of the adult body, inasmuch as this mutation affects every stage in the life-history. It is, among other attributes, a recessive mutation in eye color comparable to those in Drosophila. The same yellow element is lacking in the hemolymph and compound eye that is also missing in the egg, in the blood and body color of the caterpillar, and in the cuticula of the pupa.

\section{DISCUSSION}

Since the blood, or hemolymph, permeates all the tissues and is absorbed into the hypodermal cells, one is tempted to believe that we have here a mutation that manifests itself primarily in the blood, and that the hypodermal cells are blue-green and secrete white rather than yellow cuticula because permeated with the non-yellow hemolymph. If this conclusion is justified, the mutations in eye color in Drosophila also may be due to changes in the blood plasma, and when the nature of these physicochemical changes is ascertained we shall be a step nearer a knowledge of genes themselves. 
But in this view we must not lose sight of the chromosomes which the behavior of the spermatozoon in fertilization shows to be practically the exclusive vehicle of paternal factors and should carry in the egg the corresponding genes of the maternal parent. It is, therefore, to the chromosomes that we must look for the determiners of blue-green color. Logically, following the chromosome hypothesis, one must then suppose that the nuclei of hemopoietic cells or more probably those of the intestinal epithelium concerned with the digestion of chlorophyl carry the gene that determines the color of the blue-green blood.

No one would claim, however, that the physical basis of normal blood color in a grass-green caterpillar is inherited. As Poulton ('85) has shown, it is a substance derived from digested chlorophyl absorbed from the intestine, and is, both physically and chemically, akin to chlorophyl. The recessive mendelian factor involved is probably an inhibiting enzyme capable of neutralizing a yellow element of this plant-derived pigment diffused in the hemolymph, leaving it blue-green.

\section{EFFECT OF BLUE-GREEN BLOOD ON THE COCOON-COLOR OF A PARASITE}

That the blood of the pupa permeates the tissues sufficiently to act directly upon the hypodermis and cuticular secretion, and to determine their color independently of any possible local action of hereditary enzymes from the hypodermal nuclei, was shown conclusively by the fact that the silk spun by braconid parasites living in blue-green caterpillars was white (fig. 5), while that produced by others living in grass-green caterpillars was bright-yellow (fig. 5a).

This was demonstrated by an experiment that performed itself in an interesting outdoor culture, $1920 \theta$. The caterpillars of this brood were either grass-green or blue-green (in the $3: 1$ ratio). Several caterpillars of each color-form were attacked by a braconid (fig. 6), Apanteles flaviconchae Riley3. The

${ }^{3}$ Kindly identified for me by Mr. A. B. Gahan, of the National Museum, who "finds no difference between the specimens which spin the bright yellow cocoons and emerge from the 'green' larvae and those which spin the white cocoons and emerge from 'blue' larvae." 
larvae of this parasite rapidly develop within the tissues of the caterpillar and come to the surface of the skin, where each immediately spins a silken cocoon, normally of golden yellow. To my great surprise the braconid cocoons upon the surface of the parasitized blue-green caterpillars were not bright yellow, but pure white. After feeding upon the blue-green, yellow-free blood of the host, the secretion of their silk glands had become pure white.

Unlike white cocoon color in Plusia moneta (Bird, '03; Hawkes, '16) and Clisiocampa neustria (Hawkes, '16) that turns yellow in a moist atmosphere, white in the cocoons of Apanteles emerging from a blue caterpillar remains unchanged in the presence of moisture.

\section{CONCLUSION}

It is exceedingly probable that normal yellow silk of Apanteles flaviconchae, parasitic upon normal yellow-green caterpillars, gets its color from a xanthophylloid element in the hemolymph, derived from the food plant. This the blood of the blue-green caterpillar lacks. Consequently, the parasite of the blue-green caterpillar spins white, instead of yellow, silk.

\section{DISCUSSION}

There is in this case no opportunity to appeal to chromosomes of the spinning glands of the braconid larvae for an explanation of the yellowness of their product. The yellowness is due directly and absolutely, so far as my observations go, to the blood of the host and not to hereditary enzymes in the chromosome of the spinning glands.

That being so, we must infer that a similar explanation holds for the grass-green of the hypodermis, yellow color of the pupal cuticula, and for adult eye color, of the host, Colias philodice, for they show a similar relation to blood pigments in that if yellow is suppressed in the blood it will be laeking in the very permeable hypodermal cells and their secretions; that is, in the cuticula of the pupa and in the compound eye. Here, too, we may disregard the possible local action of the chromosomes 
for we have a more plausible explanation in the direct action of the blood.

If it can thus be shown that hereditary characters are directly determined by the physicochemical nature of the blood, and only indirectly and $a b$ initio from the physicochemical action of chromosomes, we have taken a step toward the solution of the problem of the nature of mendelian factors, for the hemolymph of a caterpillar, like the blood of the higher animals, is subject to chemical and physical methods of analysis, and we may be able ultimately to understand and control the development of mendelizing and other characters that become in a new sense 'in the blood.'

\section{HOW LAMARCKIAN FACTORS MAY REACH THE GENES}

Nor should we neglect the study of the blood in its determinative effects upon development in investigating the possibility of permanent lamarckian adaptive changes. Is the blood susceptible to physicochemical changes due to the environment that may, on the one hand, determine the course of development and, on the other, produce a corresponding change in the chromosomal enzymes, or genes, in the germ cells? If that is possible, then the blood of the offspring would react like that of the parent in the determination of development and a lamarckian mutation would be inherited.

It is beyond the scope of this paper to gather up and consider evidence for and against this view, but the reader is asked to take with some reserve Weismann's idea which since 1890 has become a biological dogma that the germ cells are so isolated from the soma and the world that their chromatin cannot be specifically changed by environmental influences, that no mechanism exists for the transfer to the germ cells of specific environmental effects that are observable in the soma. The blood, or hemolymph, in the writer's opinion, is such a mechanism. It is susceptible, especially in caterpillars, to chemical changes produced by the food. Are the chromosomes of the germ cells immune to all such changes? 
That they are not is urged by Harrison ('20), who ascribes the increasing prevalence of melanism of moths near English industrial centers to "changed metabolism favoring resistance to, or actually induced by, the use of food contaminated with metallic salts and other compounds." Melanism in moths of the genus Oporabia, however, upon which his paper treating of the possible inheritance of acquired melanism is based, unfortunately, is non-mendelian in its inheritance. A persistent blend occurs. In other words, melanism has not affected the chromosomes, though it apparently has affected the hemolymph. The next step would be to show that the hemolymph may in turn induce mutation in the chromosomes.

We may well be skeptical of 'proofs' of the inheritance of acquired mutations that are not checked up by control experiments running through more than one generation, for the origin of the blue caterpillars shows that to reveal the nature of the genes and bring out latent recessive mutations that might be ascribed to environmental factors, two or more generations of inbreeding may be necessary.

Suppose, for example, that a culture under the stress of environmental conditions should prove to contain a new recessive mutant and that a control culture of the same stock bred under normal conditions apparently does not. The usual presumption has been that the new variation has been produced by the environmental factors. The presumption, on the contrary, should be that the experimenter is working with heterozygous material, that a pair of heterozygotes have in fact produced his mutants, and that his control culture, being made up of heterozygotes mated with homozygous dominants and apparently composed exclusively of normal individuals, should be further inbred to show its real genetic constitution. No such carefully controlled experiments giving positive reliable results have yet come to the writer's attention. ${ }^{4}$

\footnotetext{
'At the time these words were written Dr. M. F. Guyer's and E. A. Smith's very important paper on the inheritance of an acquired eye defect in rabbits had not been read (vol. 31 , no. 2 of this Journal). It should have been included in this discussion.
} 
On the other hand, Federley ('20) has recently analyzed the case of supposed mutative effects of cold in Fischer's ('01) experiments with Arctia caja, and shown that the supposed positive results that have often been quoted as proof of the inheritance of acquired characters are in all probability due to the heterozygous nature of the stock.

I concur entirely with his conclusion that wild species frequently are only apparently constant, but really heterozygous for a considerable number of genes, and have emphasized this in an essay (Gerould, '14) calling the attention of systematists to the importance of testing species whenever possible by inbreeding and cross-breeding them. Federley, furthermore, makes the interesting suggestion that 'varieties' are groups of individuals showing rare combinations of genes (extracted recessives from the heterozygous type), while 'aberrations' are still rarer combinations from complexes of polymeric factors.

\section{ACTION OF ENVIRONMENTAL FACTORS AND GENES UPON CERTAIN BLOOD PIGMENTS}

There can be little doubt that the blood plasma plays an important part in the ontogenetic development of seasonal variations, which in some cases are as strikingly abrupt as mutations. An interesting example of this class of variations has recently come to the attention of the writer. Two forms of Leptalis spio, a pierid butterfly, occur in Porto Rico, specimens of the generation emerging in May being marked with orange, those of the July brood with yellow, ${ }^{5}$ the latter but not the former being an excellent 'mimic' of Heliconius charitonius. It would be interesting to discover the relation of pigments in the hemolymph to this striking change. Climatic changes in radiant energy and moisture produce periodically and rhythmically in cases like this a reversible chemical reaction in blood pigments involving a visibly abrupt variation. The seasonal difference may be said to be 'qualitative,' though it is brought about by a quantitative difference in temperature or moisture.

${ }^{5}$ To Mr. F. E. Watson, of the American Museum of Natural History, I am indebted for the idea and the evidence that this is a case of seasonal dimorphism. 
The degree of intensity or, in musical terms, 'pitch' of the seasonal variations of Colias eurytheme that I have studied and shall describe in another paper is to be explained by the direct action of environmental factors upon the blood, restraining or forcing on the chemical elaboration of orange pigments that the hemolymph lays down in the wing scales. At the same time these butterflies are subject to much individual variation due to the action of genes.

In this case, as in the subject of the present paper, the substrate upon which the chromosomal enzymes act to produce individual variations is not inherited, nor does it come from the food. It is derived from the uric acid that has accumulated during the pupal stage, which, according to Hopkins ('96) furnishes the yellow and orange pigments of Colias.

While these pigments, or this pigment, are, strictly speaking, not inherited, they are under the direct control of genes, for I have found that orange and yellow in the species-cross C. eurytheme $x$ philodice segregate through the action of two pairs of homomeric multiple factors in true mendelian fashion, enormously increasing the range of variation in $\mathrm{F}^{2}$ over that in $F^{1}$, but without abrupt discontinuity. Simultaneously the elaboration of the same orange pigment is in high degree under environmental control, especially that of temperature. What, then, is the rôle of the mendelian factors involved in orange vs. yellow wing color? They are presumably enzymes that produce a reversible chemical reaction in this particular biood pigment, as a dominant oxidase vs. its absence or a recessive reductase. The intensity of this chemical reaction (oxidation?) taking place in every individual of a given seasonal generation is practically uniformly controlled by the climatic conditions of that season, toning up or shading down the orange hue of every individual, but not determining individual variations. The evidence supporting these conclusions must be reserved for detailed treatment in a future paper.

To summarize: in this cooperative action of climate and genes upon the oxidation of these urates in the blood, climate regulates the intensity of the reaction nearly uniformly in every individual 
of a given generation (cf. the 'pitch'); genes act differentially upon individuals, determining the particular intensity exhibited by each as compared with its brothers and sisters.

INADEQUACY OF THE PRESENCE-ABSENCE HYPOTHESIS TO EXPLAIN GRASS-GREEN VS. BLUE-GREEN BLOOD COLOR

The reader is now asked to return from this digression to the main subject of this paper, pigments derived from chlorophyl, which have little in common with the yellow-orange urates just discussed except that both are dissolved in hemolymph.

A xanthophylloid yellow element is present in the blood of the dominant grass-green (body and blood color) caterpillar and absent from the recessive blue-green, but it is clearly evident that the dominant character grass-green is produced not by the dominant gene, as the presence-absence theory would imply, but is supplied by the food. We are safe, I believe, in accepting the conclusion of Poulton, Mayer, and later observers that the yellow component of green blood pigment in plant-eating caterpillars is modified xanthophyl that has left the plastids of the food plant and combined with proteids in the blood plasm. The active factor in this pair of allelomorphs is the recessive, an inhibitor or decolorizer that attacks and destroys xanthophyl on its way into the hemolymph, or otherwise suppresses the xanthophylloid pigment of normal grass-green blood. The dominant hereditary factor representing the normal grass-green is probably in this case a blank, an absence of the recessive gene, for the physical basis of the dominant yellow-green is furnished by the food. Thus, to fit this case, the presence-absence hypothesis must be inverted.

\section{ELIMINATION OF THE BLUE-GREEN MUTANTS BY NATURAL SELECTION}

English sparrows in the summer of 1920 were a serious hindrance in my breeding experiments, boldly entering the greenhouse through the open sash and feeding on caterpillars or pupae that could be reached by pecking through the screening of the cages. Outdoor cultures suffered still worse from the ravages of the birds. 
Brood $\theta$, which consisted altogether when brought into the laboratory of sixty-nine grass-green and twenty-five blue-green caterpillars, came from three successive layings outdoors, of which nos. 1 and 3 were continually covered with cages, while no. 2 on a spot close to the others was left uncovered from August 4th to 16th, owing to a lack of cages and because when setting the culture I had no great interest in it (the brood being expected to be homozygous for the common yellow-wing form). On August 16th blue-green caterpillars were discovered greatly to my surprise in cages nos. 1 and 3. Between a third and a quarter of the caterpillars in these cages were blue-green. On the spot where cage no. 2 had stood during the laying of the second lot of eggs, and which for twelve days had been uncovered and open to the attacks of birds, almost exclusively grass-green caterpillars in various stages of development were found. By careful searching I succeeded in finding two very small and not yet conspicuous blue-green larvae that had escaped the eyes of the sparrows. It was perfectly evident that the birds had found the blue-green mutants an easy mark and that, while leaving plenty of grass-green caterpillars untouched, they had eliminated from that part of the culture nearly every blue-green individual.

\section{INHERITANCE OF THE MUTATION}

The evidence that the blue-green mutation is inherited as a mendelian recessive is not extensive, yet definite and satisfactory as far as it goes.

As explained above in the section describing the origin of the mutation, the first three broods in which it appeared were from parents all of which were grass-green heterozygous dominants. These broods are shown in detail in the following table.

Inspection of table 1 shows that in the first generation the $3: 1$ ratio between grass-green and blue-green larvae was closely approached in the total number of individuals that came through to the imago, and that, in the census of all the larvae, both living and dead by disease, in each of the three families, the same proportion is evident. It will also be seen that the numbers 
TABLE 1

First generation showing the mutation

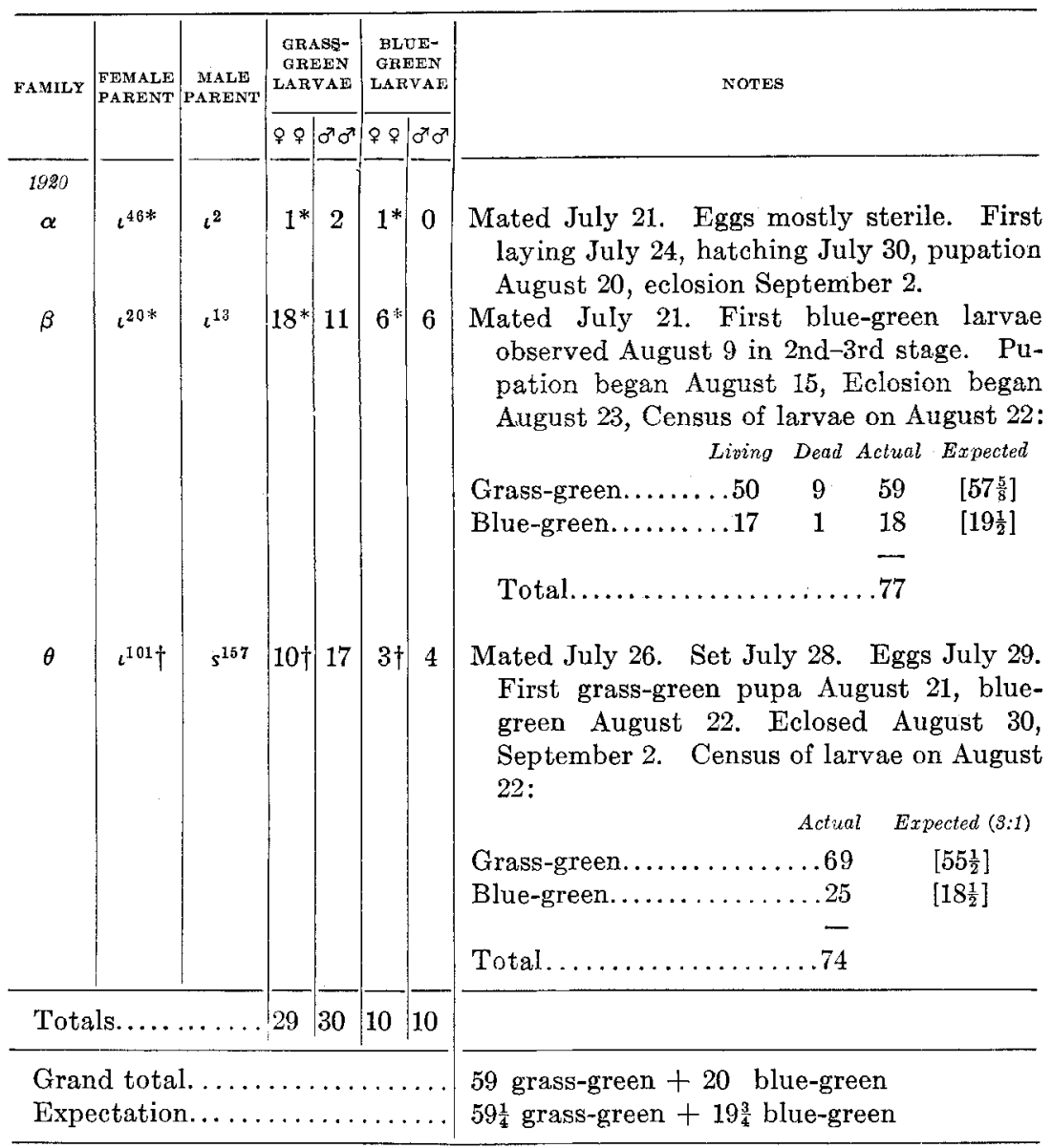

* White wings.

$\dagger$ Yellow wings. The male always has yellow wings.

of blue-green individuals are equally distributed between the sexes.

In the second generation two 'blue-green' parents gave only blue-green offspring (family $\psi$ ) and the two heterozygous 'grass-green' gave both dominant and recessive varieties, though in numbers too small to be of significance. 
TABLE 1-Continued

Matings giving a second generation

\begin{tabular}{|c|c|c|c|c|}
\hline FAMILY & $\left|\begin{array}{l}\text { FEMALE } \\
\text { PARENT }\end{array}\right|$ & $\mid$\begin{tabular}{|c|c|} 
MALEE \\
PARENT
\end{tabular} & LARVAE & NOTES \\
\hline $1920-21$ & & & & \\
\hline$\psi$ & $-\alpha^{1}$ & $-\beta^{1}$ & All blue-green & $\begin{array}{l}\text { Both parents were blue-green as larvae. } \\
\text { Mated September } 2 \text {. Few eggs laid on } \\
\text { September } 9 \text {, pure white, not cream } \\
\text { white. The few laid were mostly } \\
\text { fertile. Female inactive and weather } \\
\text { conditions unfavorable to incite egg- } \\
\text { laying. She died Septemuer } 27.5 \\
\text { larvae, all blue-green, in hibernation. }\end{array}$ \\
\hline * & $\beta^{19}$ & $\beta^{8}$ & $\begin{array}{l}\text { Grass-green and } \\
\text { blue-green }\end{array}$ & $\begin{array}{l}\text { Both parents grass-green heterozygotes, } \\
\text { but the small brood of caterpillars } \\
\text { contained an excess of blue-green, viz., } \\
6 \text { blue-green and } 2 \text { grass-green (prob- } \\
\text { ably not all the grass-green larvae } \\
\text { were seen, though they were much in } \\
\text { excess of } 25 \text { per cent blue-green). } \\
\text { Caterpillars in hibernation. } \\
\beta^{8} \sigma^{7} \text { was again mated with another } \\
\text { sister, } \beta^{20} \circ \text { giving a large brood, } \epsilon \text {, } \\
\text { of grass-green larvae. }{ }^{1} \text { Since this is } \\
\text { a } D R \times D D \text { combination, inbreeding } \\
\text { next summer is expected to bring out } \\
\text { plenty of blue-green larvae. }\end{array}$ \\
\hline
\end{tabular}

1 (Postscript, September, 1921.) From this brood, $\epsilon$, during the summer of 1921 blue-green eaterpillars were recovered, but only by mating females of $\epsilon$ to wild males and then inbreeding, as will be described in a later paper.

[Note added September, 1921: These facts regarding the inheritance of blue-green have been amply supported by the experiments of the following season (1921), when a new recessive mutant caterpillar, olive in color, producing a butterfly with olive-colored eyes, appeared in recovering the blue-green strain from grass-green after back-crossing with wild stock.]

\section{VIGOR OF THE MUTANT CATERPILLARS}

The census of brood $\beta$ as caterpillars, viz., 59 grass-green: 18 blue-green, was also perfectly definite and tends to show that the blue-green larvae are stronger and more resistant to disease 
than the normal yellow-green. Possibly this will explain the excess of blue-green individuals in brood $\theta$, notwithstanding the inroads upon one part of it by English sparrows, as described in the previous section. A similar excess of blue-green caterpillars was noted in the small family of the second generation, $\kappa$, as shown in table 1. The small size of the brood is due to infertility that accompanied inbreeding, rather than to disease. If the blue-green caterpillars should prove to be stronger and more resistant to disease (especially the virulent polyhedral disease with which the breeder of lepidoptera constantiy contends), the conspicuousness of its color is a handicap that would never allow it to succeed in the struggle for existence, unless it should find and adapt itself to a bluish-green food plant of its favorite botanic family, the Leguminosae.

\section{SIMILAR PIGMENTS}

The pronounced blue-green hue of the caterpillar, however, is not exactly matched by any pure leaf color that I know. It is physically comparable in the vegetable kingdom to the tint of the blue-green algae, which is due to a special blue pigment (phycocyanin) in addition to chlorophyl. Phycocyanin, according to West ('04), is a "reserve albuminous substance containing both nitrogen and phosphorus, and it occurs in small granules."

The source of the blue-green color of the mutant caterpillar is the blue-green component of chlorophyl from the food plant, if, as I assume, the yellow component xanthophyl, or its deoxidized derivative carotin, is destroyed, or at least changed and decolorized, during digestion, leaving only the blue-green component. The latter, formerly called chlorophyllin, is now known through the researches of Willstatter ('13) and others to be a mixture of two pigments: one of which, chlorophyl $a$, $\mathrm{C}_{55} \mathrm{H}_{72} \mathrm{O}_{5} \mathrm{~N}_{4} \mathrm{Mgg}$, constituting about 72 per cent of the mixture (with a variation of not over 10 per cent) is blue-green in alcoholic solution as seen by transmitted light, blood-red by reflected light; the remaining 26 per cent is called chlorophyl $b$, yellowgreen by transmitted light, differing from its associate in the lack of two atoms of hydrogen and the addition of one of oxygen. 
It is of course not possible to say at present that the blue-green pigment of the blood and integument of the mutant is identical with chlorophyl $a$, for certain changes may have occurred in digestion of the chloroplastids and recombination of the pigments with proteids dissolved in the hemolymph, but Poulton's ('85) studies show that spectroscopically the pigments of normal green caterpillars appear to have suffered no fundamental change from the mixture of chlorophyl and xanthophyl that make up ordinary leaf-green.

Dr. William Patten, on looking at the mutant caterpillars, was immediately impressed with the similarity between their color and that of well-oxygenated hemocyanin as seen in theblood of Limulus. A close comparison between the two was accordingly made. It was found that the gireenish hue that occurs in the mutant caterpillar's blood is lacking in hemocyanin though both, until brought together for comparison, look much alike.

The resemblance is interesting, in view of the well-known chemical similarity of the animal and plant pigments concerned with respiration and photosynthesis. Hemocyanin, hemoglobin, and chlorophyl are chemically closely related. They have definite chemical interactions with $\mathrm{CO}_{2}$ and $\mathrm{O}$, and their decomposition products, hematoporphyrin from hemoglobin and phylloporphyrin from chlorophyl, are almost identical. The possibility is at least worth investigating whether the chlorophylloid pigments of the blood of caterpillars, though not respiratory in the same sense as hemoglobin and hemocyanin, may not perform some function in connection with the elimination of $\mathrm{CO}_{2}$. The caterpillar's hemolymph is acid, as Poulton ('85) and Mayer ('97) have shown, which may be due to the presence of $\mathrm{CO}_{2}$. Moreover, Mayer pointed out that in an atmosphere of $\mathrm{CO}_{2}$ the hemolymph does not coagulate. There is no direct positive evidence, however, known to the present writer that this green blood pigment is a reducer of $\mathrm{CO}_{2}$ or performs such a supplementary respiratory function as that just suggested. If such a reaction occurs, it cannot depend, as in photosynthesis, 
upon the presence of light, for many green caterpillars feed and thrive well though enclosed in a box or jar from which light is excluded. This species, however, feeds only by daylight.

\section{FACTORS AFFECTING THE COLOR OF BLOOD AND COCOON IN THE SILKWORM}

Yellow blood in silkworms is closely correlated with the spinning of yellow silk, white blood with white silk. Ude ('19), however, has discovered a strain of yellow-blood stock that spins white silk, though their silk glands are yellow.

A homozygous mutant, i. e., yellow blood, white silk $\times$ white blood, white silk, if the latter is a genuine double recessive, gives only the double dominant yellow blood, yellow silk in $F_{1}$, which, inbred, produced 9 yęllow blood, yellow silk, 3 yellow blood, white silk, 4 white blood, white silk, showing that two pairs of factors interact, viz., C., turning blood yellow, but by itself not affecting silk, and $\mathrm{Y}$, which affects visibly neither blood nor silk unless combined with $\mathrm{C}$, when it makes the silk yellow. Moreover, not all individuals of white blood, white silk strains are double recessives. Some are either homozygous or heterozygous for the dominant yellow silk factor, $Y$, though they are of course homozygous recessives for the blood color, viz., cc.

If the yellow blood of the silkworm is due to xanthophyl from mulberry leaves, upon which point Dubois ('09) expresses some doubt, there would seem to be involved in this case two recessive decolorizing enzymes, one of general nature, c, turning the blood white, and the other, $y$, acting specifically through the nuclei of the silk glands to decolorize their product, the glands themselves, as Ude points out, not being affected. Either of the recessive decolorizers must be present in homozygous or duplex quantity in order to produce a visible result, i.e., CcYy would be yellow blood, yellow silk; Ccyy, yellow blood, white silk; ccYY or ccYy, white blood, white silk. This assumption necessitates no change in Ude's formulas and gives a working hypothesis that may be of value regarding the factors. 


\section{SUMMARY}

1. Numerous (ca. 44) conspicuous blue-green caterpillars appeared in August, 1920, in closely inbred stock of the protectively colored grass-green caterpillars of Colias philodice.

2. The three broods in which they first appeared clearly showed the 3:1 ratio, grass-green (i.e., yellow-green) being dominant, blue-green, recessive. Hence their six parents were all heterozygous (grass-green) dominants. Five of the latter were brothers and sisters, one a cousin, derived from two pairs of grandparents.

3. The matings of each of these two pairs of grandparents must have been of the type: normal (dominant) grass-green $x$ heterozygous grass-green. All four had been hibernating caterpillars, the offspring of a wild female (with white wing color) of the fall brood of 1919. She, or her mate, was probably also a heterozygous grass-green caterpillar, the other member of the pair being normal. The mutation is thus to be traced back to one of the individuals of this pair.

4. This is an example of recessive mendelian factors, (mutations) existing unsuspected in true-breeding wild stock, but brought to light by inbreeding.

5. In the second generation, the offspring of two recessives, blue-green $\times$ blue-green, bred true. A pair of grass-green heterozygotes gave an excess of recessives, but the total numbers were very small.

6. The mutation is not sex-limited.

7. Two non-inherited pigments derived from the chlorophyl of the food plant, and probably only slightly modified by digestion and combination with other proteids (Poulton, '85), are the physical basis of the dominant and recessive colors. They are xanthophyl, a yellow pigment, and chlorophyl $a$, of bluegreen color. Both probably exist together in normal grassgreen hemolymph.

8. The hereditary nuclear enzyme, or recessive gene, involved in this case is a decolorizer (inhibitor) of xanthophyl. Since it is recessive, it must be present in double dose (homozygous condition) in order to produce its effect. It 
probably acts primarily through the nuclei of the intestinal epithelium upon the digesting chlorophyl, and thereby upon the blood itself. It affects directly, or indirectly through the blood, every stage in the life-history of the, insect.

9. The egg of the butterfly from a blue-green caterpillar is pure alabaster-white, not the normal cream-white, an effect due to the lack of yellow in the blood of the mother.

10. The blueness of the blood of the larva becomes visible just before the second molt by the stretching of the skin, then relatively thick. After this molt the larva is conspicuously bright blue-green ('light procelain green' of Ridgeway).

11. There are no intermediates. It is a sharply discontinuous variation.

12. The pupa is only slightly less blue than the larva. Its cast cuticula is white, not the normal yellow.

13. The wing color of the adult is unaffected by the mutation, for females from blue-green caterpillars have either yellow or white wing colors, as determined by another independent pair of genes.

14. The eye color of the adult is affected by the mutation, probably through action of the blood. It lacks yellow and is of a bluish green ('mineral green' rather than the normal 'apple green').

15. The determination of the color of the hemolymph is primary, or direct, but that of egg, pupal cuticula and of the eye secondary, or indirect. The following observation favors the idea that at the points last mentioned the action is indirect:

16. Hymenopterous parasites, Apanteles flaviconchae Riley, emerging from a grass-green caterpillar spin bright goldenyellow cocoons, those emerging from a blue-green caterpillar spin white cocoons. The lack of xanthophylloid pigment in the blood of the blue-green host, or possibly the action of a yellowinhibiting enzyme produced by the gene in the blood, changes the color of the secretion of the silk glands of the parasite from yellow to white. Presumably, the blood affects in a similar manner the hypodermis and cuticular secretion of the hypodermal cells of the host. 
17. That blueness of blood and hypodermis, whiteness of cuticula, etc., are not due to a purely maternal blood variation but to a typical recessive mutation, is evidenced by the large numbers of blue-green caterpillars that appeared in two broods of the original generation, both showing a typical 1:3 ratio, and by the production in the next of both blue-green and grass-green larvae by heterozygous [grass-green] parents and of blue-green by homozygous [blue-green] parents.

18. Normal grass-green caterpillars of C. philodice are protected by their color against the attacks of English sparrows. From an outdoor culture exposed to sparrows for twelve days the conspicuous blue-green caterpillars were practically all eliminated, while many grass-green larvae were left unmolested (as seen by comparison with two covered lots of the same brood).

19. The blue-green caterpillar is as vigorous and diseaseresistant as the normal, but the adults are less active and less inclined to mate than their heterozygous, or normal homozygous, brothers and sisters.

20. A discussion of the relation of the blue-green blood pigment to similar pigments in plants and animals, including a mutation in blood pigment in the silkworm, concludes the paper.

\section{LITERATURE CITED}

Bird, J. E. 1903 Yellow colouring of cocoons of Plusia moneta; result of moisture. The Entomologist, vol. 35, pp. 188, 242.

Dubois, R. 1909 Recherches sur la pourpre et sur quelques autres pigments animaux. Arch. de Zool. expér. et gér., 5e Sér., T. 2, pp. 471-590.

Federley, H. 1920 Die Bedeutung der polymeren Factoren für die Zeichnung der Lepidopteren. Hereditas, vol. 1, pp. 221-269.

Fischer, E. 1901 Experimentelle Untersuchungen über die Vererbung erworbener Eigenschaften. Allg. Zeitsch. für Entomologie, Bd. 6.

Gerodud, J. H. 1914 Species building by hybridization and mutation. American Naturalist, vol. 48, pp. 321-338.

GEYer, K. 1913 Untersuchungen über die chemisché Zusammensetzung der Insektenhämolymphe u. ihre Bedeutung für die geschlechtliche Differenzierung. Zeitsch. wiss. Zool., Bd. 105, S. 349-499, Taf. 20-22.

HaAs, P., AND HILL, T. G. 1917 An introduction to the chemistry of plant products. London: Longmans, Green \& Co.

HARRIson, J. W. H. 1920 Genetical studies in the moths of the geometrid genus Oporabia (Oporinia) with a special consideration of melanism in the Lepidoptera. Jour. Geneties, vol. 9, pp. 195-280. 
Hawkes, O. A. M. 1916 On the factors which determine the cocoon colour of Plusia moneta and other Lepidoptera. Trans. Entom. Soc. London. 1916, pp. 404-411.

Hopkins, F. G. 1894 The pigments of the Pieridae. A contribution to the study of excretory substances which function in ornament. Proc. Roy. Soc. London, vol. 57, pp. 5, 6.

1896 The pigments of the Pieridae: A contribution to the study of excretory substances that function in ornament. Philos. Trans. Roy. Soc. London, vol. 186, pp. 661-682.

MAYER, A. G. 1896 The development of the wing scales and their pigment in butterflies and moths. Bull. Mus. Comp. Zool., vol. 29, pp. 209-236, 7 plates.

Morgan, Sturtevant, Muller, Bridges 1915 The mechanism of mendelian heredity. New York: Holt \& Co.

Palladin, V. I., And Livingston, B. E. 1917 Plant physiology. Blakiston, Phíladelphia.

Poulton, E. B. 1885 The essential nature of the colouring of phytophagous larvae and their pupae: with an account of some experiments upon the relation between the colour of such larvae and their food-plant. Proc. Roy. Soc. London, vol. 38, pp. 269-315.

1893 The experimental proof that the colours of certain lepidopterous larvae are largely due to modified plant pigments derived from food. Proc. Roy. Soc. London, vol. 54, pp. 417-430, pl. 3-4.

Przibram, H. 1913 Grüne tierische Farbstoffe. Pfluger's Archiv für die gesamte Physiologie, Bd. 153, S. 385-400.

Ridgeway, R. 1912 Color standards and color nomenclature, pp. 1-42, 53 colored plates. Washington, D. C., pub. by the author.

STECHE, O. 1912 Die 'secundäre' Geschlechtscharaktere der Insekten und das Problem des Geschlechts. Zeitsch. für indukt. Abstammungs- und Vererbungslehre, Bd. 8, S. 284-291.

Torama, K. 1912 On certain characteristics of the silk-worm which are apparently non-mendelian. Biol. Centralbl., Bd. 32, S. 593-607.

1913 Maternal inheritance and mendelism. Jour. Genetics, vol. 2, pp. 251-404, pl. XX.

UDE, H. 1919 On the relations between blood color and cocoon color in silkworms, with special reference to Mendel's law of heredity. Genetics, vol. 4 , pp. $395-416$.

URECH, F. 1893 Beitrage zur Kenntnis der Farbe von Insecktenschuppen. Zeitsch. wiss. Zool., Bd. 57, S. 306-384.

West, G. S. 1904 The British freshwater Algae. Cambridge Univ. Press.

WillstätTer, R., und Stoll, A. 1913 Untersuchungen über Chlorophyll. Berlin. [Summary of numerous earlier publications by Willstätter and associates.] 
PLATE 


\section{PLATE 1}

\section{DESCRIPTION OF FIGURES}

Photographs by Prof. Leland Griggs and Mr. Kenneth Robes, colored from life by Prof. Adelbert Ames.

I Blue-green mutant caterpillar of Colias (Eurymus) philodice,-a recessive to yellow-green. Xanthophylloid yellow blood pigment is suppressed by the recessive factor. Note absence of pink lateral line as well as of the yellow component of the green seen in figure $1 \mathrm{a}$.

1a Normal full-grown caterpillar of Colias (Eurymus) philodice.

2 Blue-green pupa.

2a Normal pupa.

3 Cast cuticula of blue-green pupa.

3a Cast cuticula of normal pupa.

4 Blue-green eye of adult butterfy from a blue-green caterpillar.

4a Normal eye color.

5 White cocoons spun by larvae of Apanteles flaviconchae, a parasitic braconid, that had emerged from a blue-green caterpillar. Note the absence of normal yellow pigmentation. $\times 1 \frac{1}{3}$.

5a Bright yellow cocoons spun by larvae of the same species of braconid that had fed upon, and emerged from, a normal yellow-green caterpillar. The yellow color is probably due to xanthophylloid pigment in the hemolymph of the host that is suppressed in the blue-green caterpillar.

6 Adult braconid parasite of the caterpillar of Colias (Eurymus) philodice. Apanteles flaviconchae Riley. $\times 18$ 
JOHN H, GEROOLD
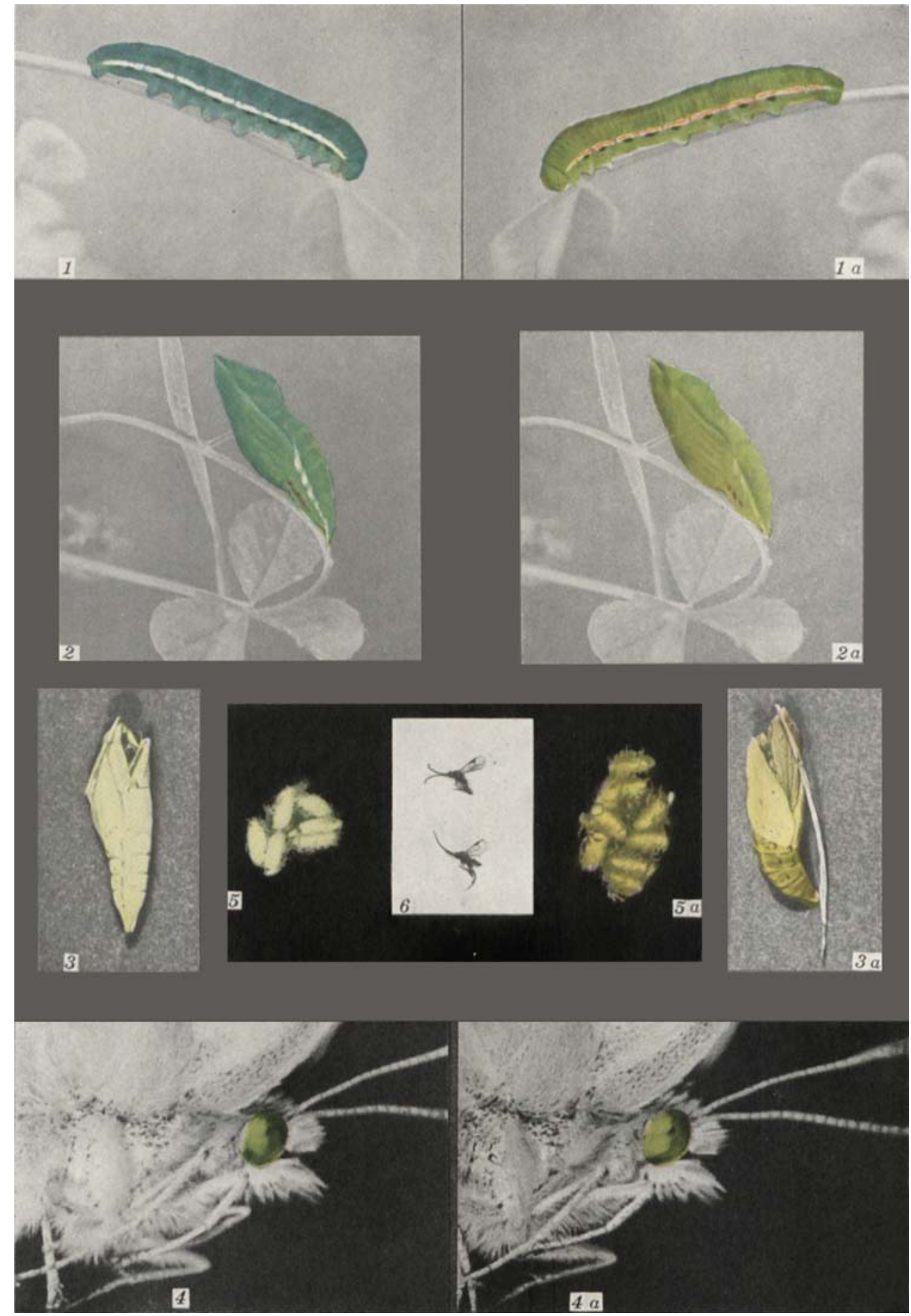